\title{
Author Index to Volume 30 - 2003
}

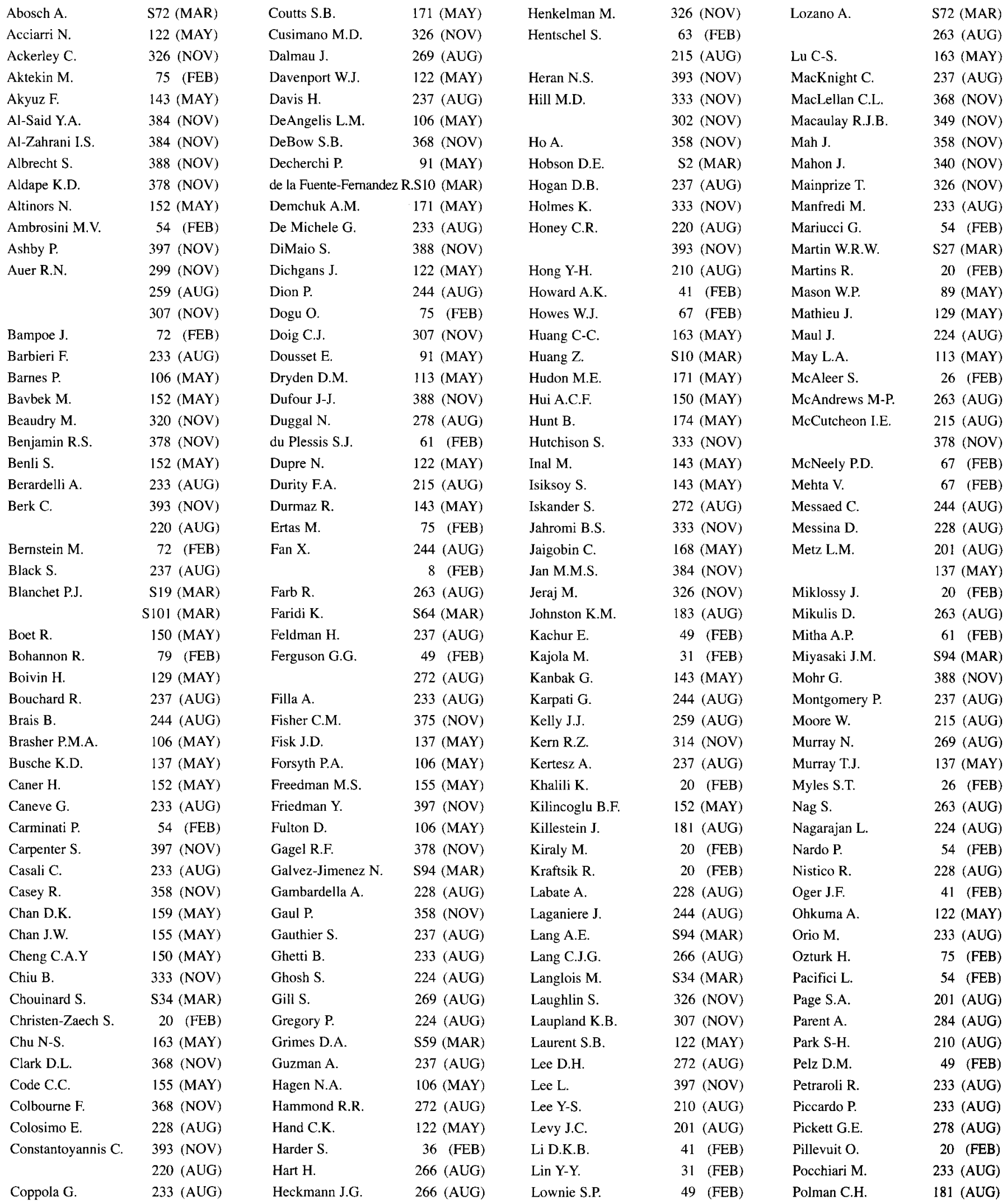




\section{Author Index to Volume 30 - 2003}

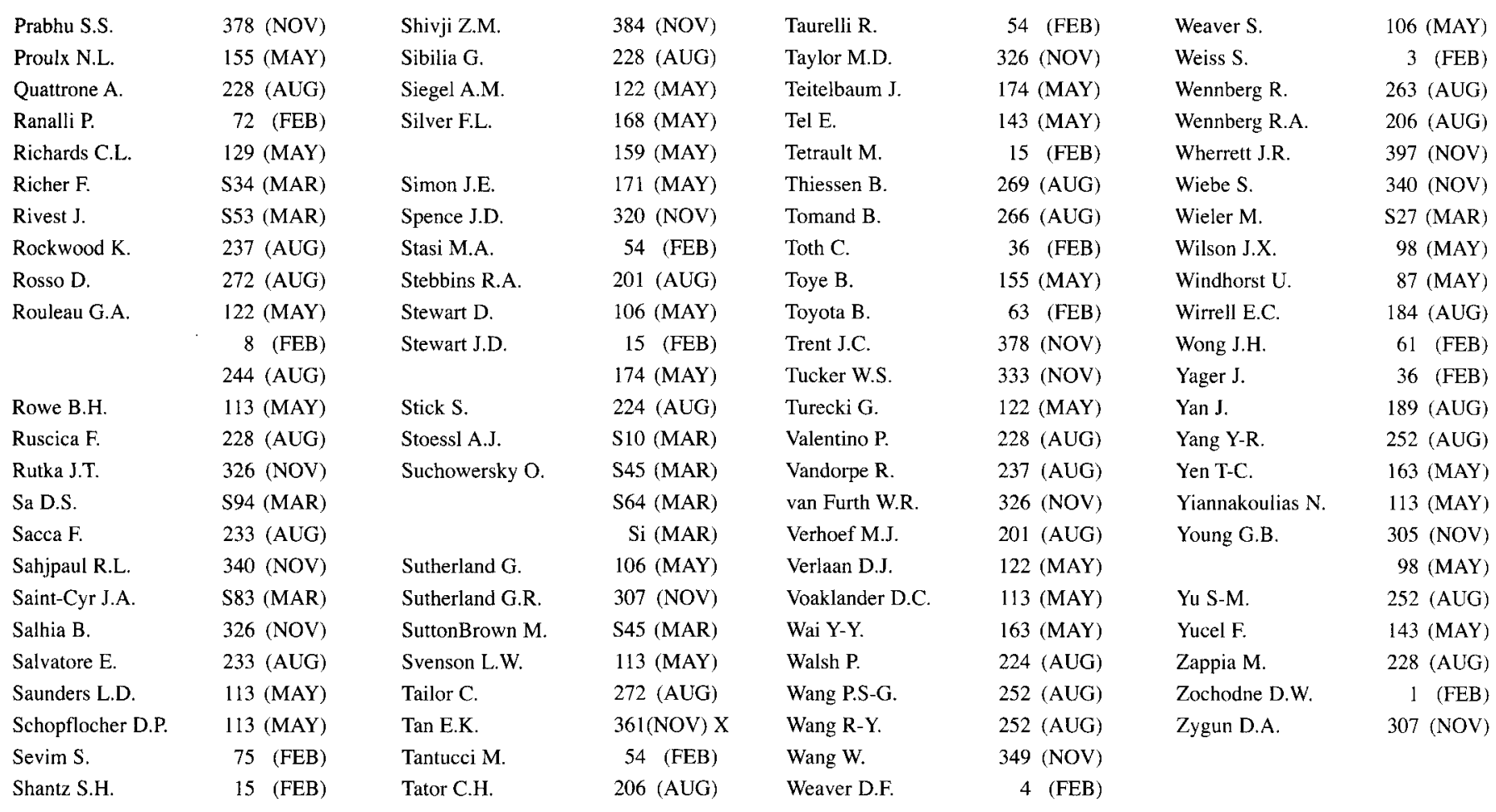

